\title{
Planning and Financing Services in the City Through Land Value Capture Instruments the Case of Tirana New Bazar
}

\author{
Anila BEJKO (GJIKA), PhD Cand. \\ Polis University, Tirana in collaboration with Ferrara University, Italy, PhD Supervisors
}

Vezir MUHARREMAJ

Polis Supervisor: Prof.

Laura GABRIELLI

Ferrara Co-Supervisor: Prof. Polis University, International School of Architecture and Urban Development Policies, Faculty of Planning, Environment and Urban Management, Department of Planning and Urban Management, Tirana,

Albania

\begin{abstract}
Objective: This paper comes as a contribution to the discussion happening in Albania related to limited funding sources for providing urban services, especially at the city level. It aims to bring some ideas on how to finance the new services that the Albanian cities need outside general budgets, or avoiding the accumulation of additional debt for local governments (LGs). Methodology: The approach suggested in the paper is to first identify the beneficiaries of any proposed improvement in providing both facilities and services, and then explore methods, which can involve the direct beneficiaries paying for their part of the benefits. The paper focuses on analyzing and reflecting upon the experience of the Municipality of Tirana for building up/refurbishing the city new bazar, and uses this as a case study to discuss on potential financing of facilities and urban services through land value capture gains, and relevant social implications in the Albanian society. Results: A value based property tax should be introduced first in Albania, not only as the instrument that can guarantee real local autonomy, but also as a precondition for applying other land value capture instruments. To mention some of the most applied ones that could also be explored in the broad Albanian context: betterment charges/fees; tax on the increment on the value of land; inclusionary housing, land assembling and land readjusting, and tradable development rights. For all of them, a substantial revision in the fiscal/public finances legislation is needed in Albania, given the fact that the relevant planning and development of territory legislation has already introduced such instruments. But above all, and what is most important, the social implications of the proposed instruments should be further researched and addressed through appropriate regulations and processes. Conclusion: Through this paper I try to demonstrate the implications of planning and financing services in the cities through land value capture instruments in the context of Albanian cities and society. Being that investments on urban services and facilities are accompanied by increases in land value, it has the features for recovering the capital costs of urban investment, by capturing some or all of the "unearned" increment in land value resulting from the investment. To accomplish this, 'novel' financing mechanisms should be used - such as land value capture instruments (betterment fees, special taxes, development agreements, etc.), but their implications in terms of improving the social fabric in the cities should be considered.
\end{abstract}

Keywords: land value capture instruments, financing urban services, novel financing mechanism, betterment fees, property tax, social fabric, city planning 